\title{
IAMJ
}

INTERNATIONAL

AYURVEDIC

MEDICAL JOURNAL

ISSN: 23205091

Impact Factor: 5.344

\section{MANAGEMENT OF INFERTILITY BY AYURVEDIC APPROACH - A CASE REPORT}

\section{Chauhan Monika ${ }^{1}$, Makeem Rita $^{2}$}

${ }^{1}$ Associate Professor, PTSR Dept., Patanjali Ayurveda College, Haridwar, PhD Scholar in Parul Ayurveda College, Vadodara, Gujarat, India

${ }^{2}$ Gude; PTSR Dept., Patanjali Ayurveda College, Haridwar, Uttarakhand, India

Corresponding Author: Chauhandrmonika1@gmail.com

https://doi.org/10.46607/iamj6008102020

(Published online: October 2020)

Open Access

(C) International Ayurvedic Medical Journal, India 2020

Article Received:26/09/2020 - Peer Reviewed:02/10/2020 - Accepted for Publication:04/10/2020

(A) Check for updates

\section{ABSTRACT}

A 32-year-old female patient complained of unable to conceive for the last 4 years. Patient had history of absent Rt. ovary and Rt. Tube and Lt. tubal blockage with multi cystic Lt. ovary. She was having history of T.O. Mass for which she underwent Rt. tube salpingectomy and right-side oophorectomy. Her HSG findings revealed Lt. tubal blockage. An Ayurveda regime including oral medications and Uttar Basti (Intrauterine medication) were planned for duration of 3 months. Post treatment HSG reveals patent Lt. fallopian tube and ultimately patient got conceived.

Keywords: Salpingectomy, Oophorectomy, T.O. Mass, Tubal Blockage, Uttar Basti.

\section{INTRODUCTION}

Mother is the most sacred and beautiful word in the world. To become mother is the first right of a woman; she becomes complete and feels proud on giving birth to a new life, but the tragedy is that all women are not Mother. This is the reason why the question of fertility is most important for women. All hazards that hamper the capacity of fertility attract unique attention for cure. In today's fast world due to lack of time, mode of life and increasing mental stress, Infertility is emerging as a major disorder affecting the social and 
psychological aspect of the life of the masses. Reproductive endocrinologists, the doctors specializing in infertility, consider a couple to be infertile if ${ }^{1}$ -

1. The couple has not conceived after 12 months of unprotected intercourse if the female is under the age of 35 .

2. The couple has not conceived after 6 months of unprotected intercourse if the female is over the age of 35 (declining egg quality of females over the age of 35).

3. The female is incapable of carrying a pregnancy to term

\section{Types of Infertility ${ }^{2}$}

1. Primary infertility: It denotes those patients who have never conceived.

2. Secondary infertility: It indicates previous pregnancy but failure to conceive. Conception depends on the fertility potential of both the Male and Female partners. Infertility is a problem of neither the male nor the female, but both are equally responsible.

The contribution of both of them is as follows. ${ }^{3}$

1. Male $30 \%$

2. Female $40 \%$

3. Both $20 \%$

4. Unexplained 10\% (D. C. Dutta)

Ayurvedic approach for infertility management

According to Ayurveda the four main factors required for the proper conception are Ritu (RituKal), Kshetra (Fertile uterus), Ambu (Amniotic fluid), and Beeja (viable Ovum and Sperm). Absence or any abnormality in any of the above factors may cause Vandhyat$v a .{ }^{4}$ Ayurveda may give a promising hand to cure this disease. As the subject matter discussed in Ayurveda, it becomes necessary to study, understand and prove them particularly in light of modern scientific parameters in the present era. So, the field of research in the Vandhyatva opens broad scope for a worker, hence this topic requires proper thought and orientation in implementation of Ayurvedic treatment of success in aimed target of attaining twinkle in the eye of childless women. So, keeping this aim in my mind, I thought to work on Female Infertility.
Case Study: A female aged 32 years, Housewife, residing in Haridwar visited Prasuti Tantra and StreeRoga OPD for treatment of failure to conceive since 4 years of active married life. In Jan 2019 patient had right sided T.O. Mass and underwent oophorectomy with salpingectomy. It means she was having history of absent Rt. Ovary and Rt. Tube and Lt. Tubal blockage with multi cystic Lt. ovary with married life of 4 years. Patient gave history of regular menstrual cycle of 28-30 days with adequate flow for the duration of 2 days without any pain. There was no contraception history and coital frequency was 1-2 times. per week. No other medical history or family history found relevant.

\section{Diagnostic Assessment}

- Blood investigations for routine workup i.e. CBC, ESR, LFT, RFT, FBS was done and found in normal range., HIV, VDRL was negative., USG showed normal Uterus and Ovary Study., Follicular study showed normal appearance i.e. one dominant follicle., S. Prolactin was $6.40 \mathrm{ng} / \mathrm{ml}$ and CA-125 was $<46 \mathrm{U} / \mathrm{ml}$., S. T3, S. T4, S. TSH was $1.01 \mathrm{ng} / \mathrm{ml}, 7.9 \mathrm{ug} / \mathrm{dl}$, 0.94uIU/ml., HSG findings showed Lt. tubal blockage with non-appearance of Rt. Tube.

\section{Therapeutic intervention}

Following treatment was given

1. Pushpadhanva rasa $-250 \mathrm{mg}$ bd

2. Kanchnaar Gugglu- $500 \mathrm{mg}$ bd

Patient underwent three cycles of Uttar Basti (Intrauterine medication therapy). For one cycle of Uttar Basti, she was instructed to come on 6th day of her menstrual cycle and advised to have a light meal in morning on the day of treatment. Abhyanga (massage) with Rasanadi Dashmool Taila and then Nadi Sweda (fomentation) of lower abdomen and back was done. After this Purvakarma, the patient was asked to lie down in dorsal lithotomy position, on the operation table. Thereafter, Yoni Prakshalana (Douching) by Panchvalkala Kwatha was performed to sterile the peri-vaginal part. Then $5 \mathrm{ml}$ of Apamarga Kshara Taila was injected with the help of IUI canula above the level of the internal OS and the patient was kept in head low position. Uttar Basti was done for three times in one cycle on alternate days i.e. on 6th, 8th 
and 10thday of menstrual cycle. The same procedure of Uttar Basti was repeated for next two consecutive menstrual cycles.

\section{Follow-Up and Outcome}

HSG was done after completion of this treatment. Findings showed normal spill from left fallopian tube which means left tube blockage was removed by this treatment regime and after 5 months she got conceived. There was no adverse or unanticipated event seen during whole regime.

\section{DISCUSSION}

Mainly Vata and Kapha are responsible for tubal blockage. The drug considered effective to open the fallopian tube should have Vata Kapha Shamaka properties. Local administration of any drug containing Sukshma, Laghu, Sara, Vyavayi, Vikasi Guna, Katu Vipaka \& Ushna Virya has effective role in removing tubal blockage. So Apamarga Kshara Taila Uttar Basti removes the blockage of tubal lumen by directly acting on obstruction and restores the normal endometrium. It restores the normal functions of cilia by stimulating it. It breaks the tubo-peritoneal adhesions, as it is observed with several studies that hysterosalpingography with oil-based dye helps to break the adhesions. It normalizes the tonic phasic contraction of muscles by pacification of Vata. It helps in scraping of obstructing substance and removes the fibrosed and damaged tubal lining and promotes its rejuvenation. Pushpadhanva rasa induces ovulation. Kanchnaar Gugglu decreases the Granthi (cyst) present in ovary.

\section{CONCLUSION}

Infertile couples are forced to dwell upon assisted reproductive techniques (ART) or Reconstructive tubal surgery after diagnosis of tubal blockage as cause of infertility. So, this Ayurveda treatment regime which includes oral medications and Uttar Basti proved to be blessing to the infertile couple.

\section{REFERENCES}

1. Infertility overview, Medscape cited on 17/5/17 at 2:30 pm available from http://emedicine.medscape. com/article/274143-overview\#a2
2. WHO, Global prevalence of infertility, infecundity and childlessness cited on 4/4/17 at 4:08 pm available fromhttp://www.who.int/reproductivehealth/topics/infe rtility/burden/en/.

3. WHO, multiple definitions of infertility cited on $4 / 4 / 17$ at 5:00 $\mathrm{pm}$ available from http://www.who. int/reproductivehealth/topics/infertility/multiple definitions/en/.

4. VriddhaJivaka. Kashyapa Samhita, preached by Maharshi Marica Kasyapa; redacted by Vatsya Commented by Hemraj Sharma, Sutrasthana (27:3), Varanasi, Chaukhambha Samskrita Sansthana, (2012) pg.25.

\section{Source of Support: Nil \\ Conflict of Interest: None Declared}

How to cite this URL: Chauhan Monika: Management of Infertility By Ayurvedic Approach - A Case Report. International Ayurvedic Medical Journal \{online\} 2020 \{cited October, 2020 $\quad$ Available from: http://www.iamj.in/posts/images/upload/4927 4929.pdf 